\title{
Chikungunya Virus
}

National Cancer Institute

\section{Source}

National Cancer Institute. Chikungunya Virus. NCI Thesaurus. Code C125638.

A species of alpha virus in the Togaviridae family. The virus is transmitted to people by mosquitoes. The most common symptoms of chikungunya virus infection are fever and joint pain. 